\title{
Relationship Between Human and Animal in Kate DiCamillo's The Magician's Elephant
}

\author{
Syafira Hardina Chairani \\ Muhammadiyah University of Surabaya, Indonesia \\ syafirahadina@gmail.com

\section{Mas'ulah} \\ Muhammadiyah University of Surabaya, Indonesia \\ mmasulah@gmail.com
}

\section{Ari Setyorini}

Muhammadiyah University of Surabaya, Indonesia arisetyorini@gmail.com

\begin{abstract}
This study aimed to analyse the relationship between human and animal in Kate DiCamillo's novel entitled The Magician's Elephant. This study analyzed how the people in The Magician's Elephant treat the animal. From the analysis in the research, the researcher found the disharmony of the relationship between humans and animals in the novel. This novel is very anthropocentric, where the people in it do not build good relations with animal, including exploiting and treating animal improperly. Ecocriticism opposes excessive exploitation of nature. All animals in the world have their own rights to life no less certainly as human do. Ecocriticism believes that animals could feel like the human in the world, aware of the world, also aware of what happens to them. Include their bodies, their freedom, even their lives. The researcher used ecocritcism theory to support this research. Qualitative descriptive is used as the research method in this research. Based on the analysis the reasearcher conclude that The Magician's Elephant have the animal right issues, where humans ought to establish good relations with nature, especially animals.
\end{abstract}

Keywords: children literature, ecocriticism, animal right

\section{INTRODUCTION}

Nature is something known through senses from the real world, such as plants, animals and many other element of the earth. Nature definition for human beings has three primary meaning: nature as the essence of a thing; nature as material place external to humanity and nature as the universal understanding that may not include human. (Ginn \& Demeritt, 2008) 
Chairani, Mas'ulah, Setyorini

TELL: Teaching of English Language and Literature Journal

Vol. 7, No 2, September 2019, DOI : http://dx.doi.org/10.30651/tell.v7i2.3179

Animals are part of nature. They are creatures which have a big role in human survival. For the example, human need them for food and help them working on field. But humans often apply arbitrarily to animals. There is a broad range of abuse to the animal, from animal prosecutions of a human for cruelty to animals to criminal proceedings of animals for crimes that allegedly committed (Tischler, 2008). Animals cannot speak so they cannot complain. This is why animals needs right. Rights cannot be obtained without also obtaining the relations that maintains them, and rights will be limited by social and human nature.

Ecocriticism is a study of culture and cultural products that have a connection with human relationship to the natural world (Glotfelty \& Fromm, 1996). Besides that, ecocritism also a response to the need for the humanistic understanding of the human relationship with the natural world in a time of environmental destruction. Ecocriticism is controlling the relationship between human and animal. How the human being selfish and they do not care about the nature especially animal.

There are two parts of ecocriticism according to Buell, the first one is anthropocentrism that is an assumption or view that interest of humans is of higher priority than those non-human. Anthropocentrism is proposed as a valid and necessary point of view for human to adopt for consideration of their place in nature (Murdy, 1975). Anthropocentrism is the grounding for some concepts of human rights. It is the necessary fundamental to defend human rights, since what matters morally is simply being human. According to Immanuel Kant, there is no proper respect given to nature and ecosystem, besides the aim is to develop human social life (Kant, 1997).

According to Buell, there are several tropes that are usually related with ecological. Those are pastoral, apocalypse and wilderness. First trope is the Apocalypse which includes nature striking back with floods, epidemics and other catastrophes (Buell, 2005). The second, pastoral which the spatial distinction of town and country as well as a temporal distinction of a fallen present and an idyllic past (Setyorini, 2016). The last is wilderness which related with desert or pole, it could be interpreted as untouchable or not controlled by human. It is a natural environment on Earth that has not been modified by human activity. The wilderness which follows the tradition of American frontier literature and fascinated with the wild as a cultural and social offering (Setyorini, 2016).

Peter Barry said in his book that ecocriticism is re-read major works from an ecocritic point of view and extend the application of ideas to areas other than the natural world. He also said that ecocriticism investigate nature, in an effort to comprehend the cultural develop-ments that have led to the present worldwide environmental crisis. (Barry, 2009)

There are four environmental areas by Peter Barry. Those are area one; the wilderness, area two; the scenic sublime, area three; the countryside, and area four; the domestic picturesque. Human move mentally through the area from 'pure' nature in the first to the dominant 'culture' in the fourth (Barry, 2009, p. 246). Area one, wilderness interpret the pure element or pure nature that human cannot deal with it. Furthermore the two middle area contain large elements of both culture and nature, but it make doubt about uncertainty positioning of some of element (Barry, 2009, p. 247). But In area four is the closest element to humans. 
In this article, the researcher found the previous study related to Kate DiCamillo about relationship between human and nature. The research showed the lack of awareness of human that affect their lives. By following nature, nature becomes the sustainability of human life. The finding of the research is people can reach what they want if they want to raise their awareness to nature and following nature. Therefore, in this article the researcher intends to analyze the relationship between human and animal in The Magician's Elephant by Kate DiCamillo's novel.

This article is a qualitative research. Qualitative research start with the assumptions and the use of interpretative or theoretical framework that advise the investigation research issues tending to the people or group attribute to a social human issue (Cresswell, 2004). The data was taken from texts, words, dialogues and setting of The Magician's Elephant novel by Kate DiCamillo.

\section{ANALYSIS}

In this part the researcher will discuss the analysis and interpretation based on the findings. Analyzing the finding will use the theories that connected to the topic about ecocriticism

\section{The Illustration of Elephant in Kate Dicamillo's Novel The Magician's Elephant.}

The story takes place in Baltese where the main character and others character are living. Peter August Duchene, a ten years old boy is a brilliant child, both of his parents were dead, but he has a big spirit to find his young sister. He lives with an old man named Vilna Luts that used to be a soldier. Peter was an orphan so he becomes a strong kid and not easily giving up. Peter is struggling his life if he found his little sister and that could happen if he follows the elephant.

One day he comes to a fortune teller and then the fortune said that he should follow the elephant to find his sister. In Baltese, there is no elephant, but someday a magician makes a wrong spell and suddenly the elephant came from the top of the building and land on a lady.

Since the elephant comes, she gets into prison, because people think that the elephant is dangerous and she already hurt one person in the show.

The elephant was imprisoned too. She was locked in a stable. A chain was

wrapped around her left ankle. The chain was attached to an iron rod

planted firmly in the earth. (DiCamillo, 2009, p. 14)

The elephant as the wild animal should be set free and brought closer to nature. According to Rollef, peoples who disagree with animal right consider torturing, exploiting, or even killing animals for unimportant things, they disbelieve that animals have the right to live (Roleff, 1999).

In mythology, symbolism and culture elephants have been portrayed as a symbol of strength and wisdom. According to the Hindu cosmology of ancient India, wisdom is represented by the elephant in the form of God namely Ganesha, one of the most popular gods in the Hindu religion. The God is very unique in having a human form with the head of an elephant (Sanstha, 1999).

Elephant as a symbol of nature treated badly without knowing what she was doing. The elephant was shocked when she fell from the ceiling, then she was blamed for accidentally landing on a woman's lap and broke her legs. The elephant is innocent, but the people only cared that the elephant is a criminal because she hurt someone. 
The elephant can feel and think like a human, she tried to remember who is she and where she is, but she cannot. As we know the elephant has a strong memory, but in this novel show, she does not remember who she is. It indicates how the elephant feels an extreme shock and makes the elephant got dizzy every thinks about it. The elephant started to feel great pain in her chest, she was hard to breathe, and she feels like the world seems too small for her. The animal also like the human, they can feel and also thinking about their self that is why animal also has animal rights.

In Asia, elephant appears in various religious traditions and mythologies. The elephants are treated positively and some of them revered as God which symbolized strength and wisdom. Asian cultures admire the high intelligence and good memory of Asian elephants (Gauding, 2009, p. 122). The phrase "Elephants never forget" refers to the belief that elephants have excellent memories. Similar in Africa, elephant is seen as the wise among the forest creatures in African fables. They also praised for their size, stamina, cooperative spirit, and loyalty. (Binney, 2006, p. 37)

Elephants are treated well in various cultures, but it is different from the elephant in this novel. She called the beast, that similar to a monster.

The beast was installed in the ballroom, and the ladies and gentlemen, dukes and duchesses, prince and princesses, and count and countesses flocked to her. (DiCamillo, 2009, p. 63)

While the elephant in the home of Countess Quintet, inside the ballroom, the elephant cannot do anything and became quite, she became the centered of the social class. It is indicated that the terminology of the beast will give the meaning that it should be tamed by the people. The elephant which has characterization as bad and wild should be dominated with people. With its large size and great strength, humans tend to consider it a beast because the elephant look dangerous and difficult to conquer. The elephant as representative of nature is being watched by humans. It indicates that the elephant is inferior to human.

All peoples in Baltese gathered around the elephant. Peoples start to fill the ballroom and touching her, pulling at her, spitting, laughing, weeping, praying and singing, but the elephant stood broken-hearted. There are many things that she does not understand. She tried to remember where her brother and sister. She starts to decide that she would like to die.

Where were the long grass and the bright sun? Where were the hot days and the dark pools of shade and the cool nights?....The world had become too cold and confusing and chaotic to bear....She stopped reminding herself of her name.... She decided that she would like to die. (DiCamillo, 2009, p. 119)

The people have to queue for a long time since there are many people want to look at the elephant for the first time. This indicates that human tends to commodify nature. Although there is no profit from the show, it also can be considered as commodification. It is because elephant, as the representative of nature becomes the part of the show, something to fulfill the desire of human. All people come to get enjoyment from watching the elephant.

The whole city of Baltese stood in line to see the elephant....And secretly, deep within their hearts, even though they knew it could not truly be so, they each expected thet the mere sight of the elephant would somehow 
deliver them, would make their wishes and hopes and desires come true.

(DiCamillo, 2009, pp. 113-114)

People in Baltese do not think that the elephant is also living beings and must be treated as living creatures. They are more concerned with satisfying their curiosity about the presence of an elephant.

\section{The Characterization of Human in Kate DiCamillo's Novel The Magician's Elephant}

\section{A. Frederick 'The Magician'}

The magician portrayed as the cause of problems that occur in Baltese. Even though he has good intentions at first, but because of his selfishness to give a spectacular show, he cast a powerful spell even though he knew that the spell was wrong. The magician only feels guilty to the Madam LaVaughn but not to the elephant. The magician never thought of the fate of the elephant, he only thought of himself while in prison. Although the elephant feels suffering because of him, he contributes to returned the elephant back through his spell.

\section{B. Peter August Duchene}

Peter is a strong kid and not easily giving up. He is ten years old and he is an orphan. He had been teaching and training as a soldier. Peter lives with Vilna Lutz, his father friend when they were a soldier. Even Peter did not have a perfect life, he still wants to struggle his life. He is a brave and brilliant boy.

$\mathrm{He}$ is one of the people who wants to set the elephant free. After seeing the elephant, peter forgot about Adele and his mother, fortune teller, and all of the people that make him can see the elephant. He forgot about everything except the truth about what he saw, what he understood in the elephant eyes. Peter makes a promise to the elephant. He vows to take the elephant home, whatever it is he wants to take the elephant back to her home. He promised to help the elephant free.

Peter is the protagonist in this novel. He has the awareness of nature than other characters. He felt the sadness of the elephant, so he helped the elephant to be free from the countess's house. But besides feel sad for the elephant, Peter also had the intention to take advantage of the elephant. He should follow the elephant if he wants to find his sister.

\section{Leo Matienne}

Leo Matienne is a Sheriff. Leo has more awareness with the animal than the other officer that says the elephant is a criminal. He feels unfair if they put the elephant into the prison, he thinks the elephant would not wish to come crashing through the ceiling of the opera house. How can the elephant feel guilty of that? Leo is giving his argument when the police chief asked why the elephant is a criminal. Other policemen say that the elephant is a criminal because she broke someone's legs. But Leo Mantine said

"Why? If the magician threw a rock at a window, would you then blame

the rock for the window breaking?" (DiCamillo, 2009, p. 30)

Leo Matienne is a good man. He is the only policeman who has empathizes with the elephant. Although he felt unfair for the elephant, he does not treat elephants well. He just felt weird to put an elephant in the prison. Leo was the person who told Peter that the countess Quintet showed the elephant for general. He helped Peter to release the elephant to return her home. 
Chairani, Mas'ulah, Setyorini

TELL: Teaching of English Language and Literature Journal

Vol. 7, No 2, September 2019, DOI : http://dx.doi.org/10.30651/tell.v7i2.3179

\section{Bettine LaVaughn}

Madam LaVaughn is a noblewoman who will initially be given a bouquet by the magician. Her legs were broken, crushed by an elephant and she should use a wheelchair. She is very desperate by the accident that happened to her. Every afternoon Madam LaVaughn comes to the prison to meet the magician, she always complaining about the same thing and saying the same word to the magician.

Madam LaVaughn blamed the magician for bringing an elephant and made her palsied but she did not blame the elephant. She never thought about the elephant life but she agreed to release the elephant from the countess Quintet's house and bring it back to the magician. She hoped that if the magician could return the elephant to its place, then the magician could also return her legs as before.

\section{E. Countess Quintet}

Countess Quintet is someone who wants to be the center of attention. She felt anxious because everyone was talking about elephants especially when she was not there when the big accident happened. She wants to be the center of the social season, so she paid a large amount of compensation to the owner of Opera house and wrote a letter concerned about the incident to Madam LaVaughn and supported her to imprison the magician.

"if everyone speaks of nothing but the elephant and if you desire to be the center, the heart, of the social season, then you must be the one with the thing that everyone peaks of." (DiCamillo, 2009, pp. 59-60)

Without caring if the elephant feels tortured, countess shows the elephant to all people in Baltese as a form of regret towards injustice to people who were not invited to the party.

The countess Quintet, after considerable and extremely careful consultation with her worried advisers, decided that the people of the city (that is, those who were not invited to her balls and dinners and soirees) could, for their edification and entertainment (and as a way to appreciate the countes's finely tuned sense of social justice), view the elephant for free, absolutely for free, on the first Saturday of the mont. (DiCamillo, 2009, pp. 76-77)

Countess Quintet is an antagonist character in this novel. She is selfish and thirst for attention. She considered herself generous because she allowed all people to see the elephant. Countess Quintet is the person who has no empathy for animals. She did not feel guilty and only concerned with her fame. She is typical of rich people who want to be center in social class.

\section{The Relationship between Human and Animal in Kate Dicamillo's Novel The Magician's Elephant}

People in Baltese tend to think anthropocentric, where nature is only a fulfillment of needs. Those people are very enthusiastic to see the elephant-like the elephant is a superstar. People always think they are special, and even feel their specialness. We all desire and seek pleasure, happiness, well-being for ourselves or for those we love.” (Butchvarov, 2015)

Peter August who is the main character also had the initial intention to use an elephant as a guide. He wants the elephant to find his sister. Traditional Western anthropocentric attitudes express a position that human beings are importance, and other species and things only matter if they are useful to humans (Sydney, 2016). His awareness of the rights of animals growing 
when he feels the elephant's emotions. He released the elephant, but on the other hand, he got the advantage from that, he could find his sister by following the elephant like the fortune teller said. Peter who wants to use the elephant for his interests by following anthropocentrism thinks that only humans have values, and nature has no value to itself

.This is contrary to ecocentrism, where human should not use the animal to benefit their self (Bousfield \& Brown, 2010). Animals should be treated with the same respect as humans. Ecocentrism against about how the human being selfish and they do not care about nature especially animal. Humans and animals must be mutually beneficial.

At the time of the arrival of the elephant in Baltese, the people also blame the innocent elephant for broke the women's legs. They put the elephant in prison. The sheriff namely Leo Matienne, feels unfair to put the elephant in prison because he thinks the elephant does not know what she did. But the elephant still locked up in prison and shackles.

She was locked in a horse stable. A chain was wrapped around her left

ankle. The chain was attached to an iron planted firmly in the earth.

(DiCamillo, 2009, p. 14)

The sheriff as the one who has power, starts to mistreat the elephant. People think that it is the best solution to punish the elephant. Like Tiscler said, the animal has always been the subject of the mistreatment (Tischler, 2008).

Due to lack of knowledge about animals, peoples equated an elephant as a criminal, because no law defends animals. There is no law regulating animals, so the animal should be punished as well as the bad persons should be punished. The police act fairly in the wrong way. They should consider the animal legal issues from the perspective of the animal's awareness. The elephant as a wild free animal, should not put in a room without connection with the natural world.

Animals do not willingly sacrifice themselves for the advancement of human welfare. Their decisions are made for them because they cannot vocalize their own preferences and choices. In ecocritical, human as more intelligent beings must be aware and defend the rights of animals. Animals cannot make their own rules so people should understand that they have different rights and obligations than humans.

The Magician's Elephant shows that humans are superior rather than nature and human life has more value while other entities like animals, plants, and mineral resources are resources that may exploit for the benefit of humankind. It is represented with the characters and other people in Baltese who never thinking of the elephant's right. As social beings, humans should realize how humans worthless while living in this world without nature.

Since the beginning of the story, Baltese was described as a gloomy town. The setting of the place in this novel more often in the market. The people at the city are talked and laugh at the market. Peter, the main character, met with the fortune teller on the market too.

That day in the market square, in the midst of the entirely unremarkable and absolutely ordinary stalls of the fishmongers and cloth merchants and bakers and silver-smiths, there had appeared, without warning or fanfare, the tent of a fortuneteller. (DiCamillo, 2009, p. 2)

This indicates that the average Baltese population is middle to lower class people. The incident of the elephant had spread widely through the rumors circulating in the market. 
Chairani, Mas'ulah, Setyorini

TELL: Teaching of English Language and Literature Journal

Vol. 7, No 2, September 2019, DOI : http://dx.doi.org/10.30651/tell.v7i2.3179

People in Baltese are described as friendly to one another but not to the elephant. Lack of understanding and empathy for animals is considered normal and unnecessary.

Besides that, the weather at Baltese illustrates the suffering of the elephant waiting for the miracle. Winter came and the sun almost rarely seldom is seen, but at least the snow may fall.

No one could recall a winter so thoroughly, uniformly gray.... Where was the sun? .... Would it never shine again? .... And if the sun was not going to shine, then could it not at least snow? .... Something, anything! (DiCamillo, 2009, p. 74)

The winter without the sun can mean the sadness and the fear of the elephant. But, she but still has hope in her life. The word "and if the sun was not going to shine, then could it not at least snow?" is a form of hope for the elephant, although she cannot go home at least she can be free from the place that tortured her. The severe weather can also describe the lack of awareness of the people in the city, how nature sad because of what people have done to nature.

The disharmony of the relationship between humans and animals was shown in this novel. Even the weather at the Baltese can feel the suffering of the elephant, but not with the people. People miss the elephant, they miss the beast. Some of them bother the elephant and tried to break down the door where the elephant was locked up. They want to see the magician's elephant.

More than a few of the ordinary citizens of Baltese took it upon themselves to knock at the elephant door. When no one answered the knock, they went as far as to try to open the door themselves, but it was locked tight, bolted firm. (DiCamillo, 2009, p. 75)

Opposite with ecocentrism that people should have the concept that humans and nature ought to have respect each other. Accordance with Buell, ecocentrism respects the relationship between humans and non-humans and also the relationship between the living and non-living (Buell, 2005).

The environment described in the novel can be classified as area four, which is related to a culture based on Peter Barry theory. Humans consider culture as 'civilization' the opposite of 'nature'. In Baltese's culture think that humans have a higher moral status and level of sentience than other animals.

From the source, the story takes place in Baltese, a small town in Eastern Europe. It takes at the end century before last. That can conclude it is in the late 1800s through the early 1900s. In that time, fortune tellers were very popular, and also magic shows were as popular as the fortune teller.

In those years the Eastern European was classified as an area with a low economy from all of Europe. The eastern European experienced prolonged suffering caused by war. These things indicate that people in Eastern Europe also have low knowledge. In this novel, it is told that people in Baltese never saw elephants. People in Baltese got entertainment by watching the orchestra, a magic show, and dancing. It is not surprising that they do not know how to treat animals wisely. 
Baltese city got new entertainment. Everyone can enjoy this entertainment, from babies to adults, men and women, rich and poor in droves to see the elephant. They consider the elephant as a miracle, but they forget that the elephant is also a living creature. When it should be human always treat animals gently and eliminate the human-made cause of the animal suffering (Bousfield \& Brown, 2010).

In this novel, the elephant has brought new habits to people at Baltese. Since the arrival of the elephant, all humans in this novel seemed to be crazy about the elephant. People in Baltese were very excited and talk about it everywhere, even the puppet shows in the elephant that came crashing onto the stage. The rumors about the incident of the elephant spread rapidly among people.

The people of the city of Baltese became obsessed with the elephant.... In the market square and in the ballrooms, in the stables and in the gaming houses, in the churches and in the squares, it was "the elephant," "the elephant that came through the roof," "the elephant conjured by the magician," "the elephant that crippled the noblewoman". (DiCamillo, 2009, p. 55)

The bakers made a pastry which called the elephant ears, people seem to never get bored of eating it. The street vendors sold chunks of plaster that had fallen with the elephant at a high price. Even in the church of the pastors preaching about the elephant.

From the pulpits of the churches, the preachers spoke about divine intervention, the surprises of fate, the wages of sin, and the dire consequences of magic gone afoul. (DiCamillo, 2009, p. 55)

The Magician's Elephant shows how the elephant as a symbol of nature can change people's habits and perspectives. The existence of the elephant disturbs the social class that already exists in society. This does not only apply to lower social classes but also applies to upper social classes. This indicates that events that occur in nature can have a major influence on human survival. This understanding should be possessed by people in Baltese, without natural interference, human survival would not be guaranteed.

Countess Quintet who felt the elephant ruining the social season in upper class society, ambitious to have the elephant to raise her social class. She paid a penalty of losses to the owner of the opera house and wrote her deep condolences to Madam Lavaughn. She claimed that the elephant is her property.

The elephant, you will now understands, belonged, lock, stock, and barrel, to the countess. (DiCamillo, 2009, p. 63)

She put the elephant in her big ballroom, then the elephant becomes the show to the whole city, it does not show because the elephant just stands still, frightened and does nothing. Countess Quintet let her colleague see the elephant first then she decided to let citizens look the elephant without paying. All people come to the ballroom to get enjoyment from watching the elephant. The people of Baltese have commodified the elephant as the source of happiness for them. When humans decide the fate of animals, the animals' rights are taken away without any thought of their well-being or the quality of their lives.

Based on the data above, it appears that humans begin to be uncontrollable. This uncontrolled behavior is in accordance with the wilderness. The trope of wilderness follows 
Chairani, Mas'ulah, Setyorini

TELL: Teaching of English Language and Literature Journal

Vol. 7, No 2, September 2019, DOI : http://dx.doi.org/10.30651/tell.v7i2.3179

the tradition of American frontier literature and fascinated with the wild as a cultural and social offering (Setyorini, 2016).

The characteristic element in The Magician's Elephant was the wilderness, which is the wilderness of people in Baltese. In this case, humans cannot be controlled to exploit the elephant. Their behavior makes nature suffering. Where it should be humans that keep nature from being damaged or extinction, but in this novel nature which keeps people for staying in their social class.

Placing an elephant in the middle of the party is also a big mistake. The elephant can feel stressed and this can affect death. Humans should not inflict pain or death on animals (Bousfield \& Brown, 2010). The elephant is a symbol of the wilderness that should not be touched and left free to maintain its sustainability. But in this novel, the elephant used as a display in the party to maintain the continuity of the social season.

The glitter of the chandeliers, the thrum of the orchestra, the loud laughter, the smells of roasted meat and cigar smoke and face powder all provoked in her an agony of disbelief. (DiCamillo, 2009, p. 76)

Besides exploiting, people at the Baltese also do not care about the condition of nature, For example, the magician who causes the problems that occur in Baltese, never thought the fate of the elephant, he only thought of himself while in prison. He only feels guilty to the Madam LaVaughn but not to the elephant. Also, Madam LaVaughn, even though she did not blame the elephant, but she never thought about the elephant life.

As a person who cause the problem for nature, in this case, the magician who brings the elephant. Then he must also be responsible for protecting nature. Fix what has been damaged. Either returning the elephant with his spell or taking him away from Baltese. Keep nature away from more severe damage

.The wildness of people in Baltese is illustrated by how these people treated the elephant.

In the home of the count and countess Quintet, inside the ballroom, as the people filed by her, touching her, pulling at her, leaning against her, spitting, laughing, weeping, praying, and singing, the elephant stood brokenhearted. (DiCamillo, 2009, p. 119)

The word, 'brokenhearted' can be interpreted that nature has been damaged because of human greed. The elephant act as if she is water which fulfilled the needs of human's thirst.

This action surely could not be tolerated, as long as people could remember that the right animals are the right to process freedom of life. It could be said that they did not care about the existence of the elephant. Animal just like the human in the world, aware of the world, also aware of what happens to them, and what happens to them include their body, their freedom, even their life is a matter to them. Human should be aware of it, whether anyone else cares about this or not (Regan, 2013). Therefore, animals' lives should be respected because they have an inherent right to be treated with dignity. The harm that is committed against animals should not be minimized because they are not considered to be "human."

\section{CONCLUSION}

This research focused on the relationship between human and animal in Kate DiCamillo's novel The Magiciant Elephant. The researcher finds that elephant as represent of 
nature used as a spectacle to satisfy human desires for entertainment. The elephant is considered a criminal and a beast. The elephant has been the subject of the mistreatment.

The researcher found that disharmony of the relationship between humans and animals. How the human being selfish and they do not care about the nature especially animal. People in this novel tend to think anthropocentric, which a position that human beings are importance, and other species and things only matter if they are useful to humans.

So, the conclusion is this novel is very anthropocentric, where it should be humans must establish good relations with nature, especially animals. Ecocriticism opposes excessive exploitation of nature. All animals in the world have their rights to life no less certainly as human do. Ecocriticism believes that animals could feel like the human in the world, aware of the world, also aware of what happens to them. Include their bodies, their freedom, even their lives. Unfortunately, animals could not defend themselves, because of that human should aware of animal rights. Mutual respect between nature and human that applied by ecocriticism create harmony so in the future world, there will be less mistreatment to nature especially animal.

\section{REFERENCES}

Barry, P. (2009). Beginning Theory: An Introduction to Literary and Cultural Theory. Manchester: Manchester University Press.

Binney, R. (2006). Nature's Ways Lore, Legend, Fact and Fiction. David \& Charles.

Bousfield, B., \& Brown, R. (2010). Animal Walfare. Bulletin, Kowloon: Agriculture, Fisheries and Conservation Department Newsletter.

Buell, L. (2005). The Future of Environmental Criticism: Environmental Crisis and Literary Imagination. Oxford: Blackwell Publishing.

Butchvarov, P. (2015). Anthropocentrism in Philosophy. De Gruyter.

Cresswell, J. W. (2004). Qualitative Inquiry \& Research Design Choosing Among Five Reasearch. Thousand Oaks: Sage Publications.

DiCamillo, K. (2009). The Magiciant's Elephant. Massachusetts: Candlewick Press.

Gauding, M. (2009). The Signs and Symbols Bible. New York: Sterling Publishing Co.

Ginn, F., \& Demeritt, D. (2008). Nature: A Contesed Concept.

Glotfelty, C., \& Fromm, H. (1996). The Ecocriticism Reader: Landmarks in Literary Ecology. Georgia: The University of Georgia Press.

Kant, I. (1997). Lectures on Ethics. Cambridge University Press.

Murdy, W. (1975). Anthropocentrism: A Modern Version.

Roleff, T. L. (1999). The Rights of Animals. Greenhaver Press.

Sanstha, B. S. (1999). Ganesh Chaturthi. Dipetik July 11, 2019, dari BAPS Swaminarayan Sanstha: http://www.swaminarayan.org/festivals/ganeshchaturthi/index.htm

Setyorini, A. (2016). Ecology, Technology and Dystopia: an Ecocritical Reading of Young Adult Dystopian Literature. In Proceedings of International Conference on Language, Literary and Cultural Studies (ICON LATERALS) (pp. 100-115).

Tischler, J. (2008). Stanford Journal of Animal Law and Policy. The HIstory of Animal Law PArt I. 